\title{
Prevalence of Systemic Arterial Hypertension in Quilombola Communities, State of Sergipe, Brazil
}

Deyse Mirelle Souza Santos, Beatriz Santana Prado, Cristiane Costa da Cunha Oliveira, Marcos Antonio Almeida-Santos ${ }^{\circledR}$

Universidade Tiradentes, Aracaju, SE - Brazil

\begin{abstract}
Background: The quilombolas are groups formed by black ancestry individuals, living in a context of social vulnerability due to low socioeconomic level, which influences health care and the development of chronic diseases.
\end{abstract}

Objective: To assess the prevalence of systemic arterial hypertension and its association with cardiovascular risk factors in the quilombola population in the State of Sergipe, Brazil.

Methods: Study design was cross sectional, involving the administration of a questionnaire to individuals aged $\geq 18$ years, in 15 quilombola communities of the State of Sergipe, Brazil. A value of two-sided $p<0.05$ was considered statistically significant.

Results: sA total of 390 individuals were evaluated, $72.3 \%$ of whom were women, with a mean age of 44.7 years. The prevalence of hypertension was $26 \%$ (with a confidence interval of $95 \%$ [95\% Cl]: $22-30$ ), with no significant sex-related differences. The age was associated with arterial hypertension (95\% CI: 1.03-1.06), systolic (95\% Cl: 1.04-1.07) and diastolic (IC 95\%: 1.01-1.04) arterial hypertension. The level of body mass index was associated with arterial hypertension (95\% Cl: 1.00-1.11) and diastolic arterial hypertension (95\% Cl: 1.03-1.17). Economic class was associated with diastolic arterial hypertension (95\% Cl: 1.22-5.03).

Conclusion: The prevalence of arterial hypertension in the quilombola communities was high. Its association with cardiovascular risk factors indicates the need to improve access to healthcare services. (Arq Bras Cardiol. 2019; 113(3):383-390)

Keywords: Cardiovascular Diseases; Hypertension; Prevalence; Public Health; Risk Group; African Continental Ancestry Group; Health of Specific Groups.

\section{Introduction}

The quilombolas are groups formed by black ancestry individuals, due to their African origin, trafficked to Brazil between the XVI and XIX centuries. They were brought to work as slaves in the sugar plantations under precarious conditions. After the abolition of slavery, numerous quilombola communities arose in Brazil; nowadays there are 2,958 communities throughout the country, and 35 are located in the State of Sergipe. The States of Bahia, Maranhão, Pará, Minas Gerais and Pernambuco have a higher number of communities in their territories. ${ }^{1}$ The land demarcated as quilombola territories ensure the physical, social, economic and cultural reproduction of the remaining members of the Quilombo communities. ${ }^{2}$

The quilombola communities are inserted in a context of social vulnerability due to low socioeconomic level, which directly influences healthcare and the development of chronic diseases. ${ }^{3}$ Studies have shown that systemic arterial

Mailing Address: Marcos Antonio Almeida-Santos •

Universidade Tiradentes - Programa de Pós-graduação em Saúde e Ambiente

- Av, Murilo Dantas, 300. Postal Code 49032-490, Aracaju, SE - Brazil

E-mail: virtual.596@gmail.com

Manuscript received June 28, 2018, revised manuscript November 15, 2018 accepted December 19, 2018

DOI: $10.5935 / a b c .20190143$ hypertension $(\mathrm{SAH})$ is one of the most relevant diseases among the quilombola populations, and can be associated with genetic factors. However, Brazilian studies could not associate genetic polymorphism with increased blood pressure levels among the quilombolas, which may be associated with the intense Brazilian miscegenationa. ${ }^{4,5}$

The prevalence of $\mathrm{SAH}$ among quilombola communities has ranged from $38.4 \%$ to $45.4 \%,{ }^{7}$ which represents a higher percentage rate compared to the general Brazilian population. ${ }^{8}$ The risk factors for the development and grievance of arterial hypertension are diseases like dyslipidemia, abdominal obesity, glucose intolerance, diabetes mellitus (DM), in addition to modifiable factors, such as socioeconomic determinants and inadequate access to healthcare services. ${ }^{9} \mathrm{SAH}$ can cause permanent damage to individuals through the onset of cardiovascular, cerebrovascular and kidney diseases. ${ }^{10}$

Thus, the aim of this study was to identity the prevalece of $\mathrm{SAH}$ and its association with cardiovascular risk factors in the quilombola population of the State of Sergipe, Brazil.

\section{Methods}

The study design and sample

This is a cross sectional study, carried out in quilombola communities in the State of Sergipe, Brazil, in the period between September 2016 and April 2017. The sample delineation 
was performed through random selection in the quilombola communities, using the existing proportion of the population in the communities. These data were provided by the National Institute of Colonization and Agrarian Reform (INCRA). ${ }^{1}$

A random sample of clusters was selected in two stage cluster sampling. There are 35 quilomobola communities registered in the State of Sergipe, distributed in eight territories, of which four were randomly selected. Out of these four territories, 15 communities were randomly selected from a total of 19 . Between $15 \%$ and $20 \%$ of the adult population voluntarily participated. For each stage, once the territories and the quilombola communities were registered, the random sampling without replacement was performed using the Stata ${ }^{\circledR}$ version 15.1 software.

The communities studied are far from the city headquarters, in areas of difficult acess. Certain communities (Resina and Pontal da Barra) surround the main river in the region and the sea, respectively. The other communities (Mocambo, Canta Galo, Pirangy, Terra Dura, Forte, Caraíbas, Bongue, Patioba, Ladeiras, Alagamar, Aningas and Quebra Chifre) are situated in large land properties. The quilombola community "Maloca" is the only one that is located in urban area among the other remaining communities in the state. ${ }^{1}$

The target population of the research, according to oficial registries, ${ }^{1}$ was estimated in 1,979 adult individuals, inhabitants of the 15 quilombola communities. Sample size calculations were done using the $\mathrm{G}^{*}$ Power 3 software, ${ }^{11}$ respecting the following parameters: $80 \%$ power; two-sided alpha $=0.05$; covariable distribution pattern; log-normal distribution; potential correlation between predictors, 0.80 ; expected prevalence of arterial hypertension in the general population (20.4\%). ${ }^{8}$ According to these parameters, about 350 individuals would be necessary to detect an odds ratio $\geq 1.5$ for differences between categorical predictors, in multiple regression logistic analysis. With the aim of preserving these characteristics in a potential situation of missing data, the sample size was increased to about $10 \%$, totalling 390 individuals.

The inclusion criteria adopted for individual selection were: age $\geq 18$ years; and being registered as quilombolas in the communities where they belong and in the INCRA. The exclusion criteria were: practice of physical exercise in the last 60 minutes; ingestion of alcoholic drinks, coffee or food; use of cigarette or consumption of other substances within the 30 minutes prior to blood pressure measurement; pregnancy; and amputated upper limbs.

\section{Clinical and Sociodemographic Data Collection}

The data were collected using individual interview. The interviewers were trained for this procedure. The interview instrument used was a semi-estructured questionnaire adapted from the following studies: the Brazilian Ministry of Health's Food Guide ${ }^{12}$ and the Evaluation of Physical Activity Program Effectivity in Brazil, ${ }^{13}$ both published by the Brazilian Ministry of Health; the National Household Sample Survey $;^{14}$ the criteria of economic classification of the ABEP (Brazilian Association of Market Research Firms), which divides society into economic classes A, B1, B2, C1, C2, D-E, considering household assets, education level and the public services available. ${ }^{15}$ The questions related with licit and illicit drugs were based on the Brazilian version of ASSIST (Alcohol, Smoking and Substance Involvement Screening Test) ${ }^{16}$ The previous history of diseases was based on the questions asked for admission to hospital due to primary care-sensitive conditions. ${ }^{17}$

Then, three blood pressure measurements were perfomed (with a 1-minute interval between each measurement) A Welch Allyn DuraShock ${ }^{\mathrm{TM}}$ DS44 (Welch Allyn, Curitiba, Brazil), internationally validated, Aneroid Sphygmomanometer, with nylon cuff and metal clasp, was used. The measurements were performed at the end of the interview.

During BP measurements, the individuals remained seated, with their legs uncrossed, feet flat on the floor, back supported by the back of a chair and relaxed. The individual's left arm was positioned for measurement, followed by the right upper limb. The third measurement was performed on the limb that presented the highest value, always with the arm rested on a table, at heart level.

For analysis, the mean of the three measurements was calculated, which corresponded to the research criteria, being considered hypertensive those individuals who had systolic arterial pressure $\geq 140 \mathrm{mmHg}$ and/or diastolic arterial pressure $\geq 90 \mathrm{mmHg}^{.}{ }^{9}$ These more conservative measurements have been adopted because the three measurements of the blood pressure were performed in only one day. For this reason, the classification of the American Heart Association was not adopted. ${ }^{18}$

The Body mass (BMI) index $\left[\mathrm{kg} / \mathrm{m}^{2}\right]$ was estimated to evaluate the anthropometric measurements (weight and height). The BMI found was categorized according with the following measures: low weight, $<18.5 \mathrm{~kg} / \mathrm{m}^{2}$; normal weight, 18.5 to $24.5 \mathrm{~kg} / \mathrm{m}^{2}$; overweight, 25 to $29.9 \mathrm{~kg} / \mathrm{m}^{2}$; level obesity, 30 to $34.9 \mathrm{~kg} / \mathrm{m}^{2}$; level II obesity, 35 to $39.9 \mathrm{~kg} / \mathrm{m}^{2}$; and level III obesity, $>40 \mathrm{~kg} / \mathrm{m}^{2} .{ }^{19}$

\section{Statistical analysis}

Categorical variables were expressed as absolute numbers and percentage. The continuous variables were expressed as mean and standard deviation. To produce robust estimates independent from the distribution pattern of the variables, some tests were specifically adopted. sThe comparisons between continuous variables and two groups were performed using the unpaired student t-test with adjustment for heterogeneity of variance and degrees of freedom using the Satterthwaite method. Comparisons between continuous variables and more than three groups were estimated using the Kruskal-Wallis test. Several logistic regression models for $\mathrm{AH}$ were used, starting from the choice of predictors with $p<0.20$ in unadjusted analyses. The model's potential increment was assessed after inclusion of squared terms and interaction of predictors. The comparison of the increased prevalence between the quilombola communities and the population in general was performed using the chi-squared adjustment test. To adjust the analysis for the differences between groups and the potential of heteroskedasticity in the quilombola communities, the Huber-White method was used to estimate clustering, robust standard errors, according with the 15 communities. 


\section{Original Article}

The estimate of the effect size was presented in odds ratio with 95\% confidence interval. The Hosmer-Lemeshow test and C-statistics (area under the receiver operating characteristic curve, or ROC curve) were used to assess the potential calibration and discrimination of the model, respectively. A value of two-sided $p<0.05$ was considered statistically significant and the Stata ${ }^{\circledR}$ version 15.1 software (Stata Corp, College Station, TX, EUA), was used for data analysis.

\section{Results}

A total of 408 volunteers participated in the research; out of these, 18 were excluded: four of them who reported being pregnant, and 14 because they had consumed alcohol. A total of 390 individuals were deemed eligible, $72.3 \%$ women and $27.7 \%$ men. There were no missing data. The age ranged from 18 to 101 years, with a mean equal to $44.7 \pm 19$ years. The skin color was self-reported, according to the criteria of the Brazilian Institute of Geography and Statistics (IBGE), which indicated that $50 \%$ of the individuals were brown-skinned. The most prevalent level of education was illiterate/incomplete primary education I (58\%). In the economic field, classes D and E obtained greater representation (76.41\%). Table 1 presents the frequency of the main sociodemographic characteristics of the quilombola communities studied.

A prevalence of $26 \%$ (95\% Cl: 22-30) was observed for $\mathrm{SAH}$; systolic arterial hypertension in $22 \%(95 \% \mathrm{Cl}: 18-26)$ and diastolic arterial hypertension in $16 \%(95 \% \mathrm{Cl}: 12-20)$ of the cases. A chi-square test was performed to compare the prevalence of $\mathrm{SAH}$ in the quilombola communities and in the general population of Sergipe $(20.4 \%),{ }^{8}$ and the quilombola communities had a significantly higher prevalence $(p=0.0071)$.

The mean number of years with a previous $\mathrm{SAH}$ diagnosis was 9.59 (standard deviation = 8.66). The diagnosis of the disease had been made at a minimum age of 18 years and at a maximum age of 55 years.

There was no significant sex-related differences between the subclassifications of blood pressure. In women the average value of systolic pressure was $125.35 \mathrm{mmHg}(95 \% \mathrm{Cl}$ : $122.7-$ 127.9), whereas in men the average value was equal to 129.53 $\mathrm{mmHg}(95 \% \mathrm{Cl}: 125.3-133.7) ; p=0.09$. The average diastolic pressure value estimated for women was $78.88 \mathrm{mmHg}(95 \%$ $\mathrm{Cl}$ : 77.1-80.6); as for men, the average value was $78.57 \mathrm{mmHg}$ (95\% Cl: 76.3-80.7); $\mathrm{p}=0.83$.

Among the behavioral variables reported by the participants, the following percentages were obtained: smoking, 37.18\%; having alcohol drinking habits, $60.77 \%$; and being physically inactive, $44.10 \%$.

The participants responded that they consumed high quantities of sodium chloride (salt) everyday $(17.69 \%)$. In relation to the anthropometric parameters, about $60.01 \%$ of the population presented with overweight or classes I, II and III obesity, with a smaller number of normal weight individuals (37.17\%) (Table 2).

Table 1 - Distribution of the demographic and socioeconomic variables in quilombola comunities in the State of Sergipe, Brazil, 2016-2017

\begin{tabular}{|c|c|c|}
\hline Variables & $\mathbf{N}$ & $\%$ \\
\hline \multicolumn{3}{|l|}{ Age } \\
\hline 18 to 49 & 245 & 63 \\
\hline 50 to 79 & 133 & 34 \\
\hline$>80$ & 12 & 3 \\
\hline \multicolumn{3}{|l|}{ Sex } \\
\hline Female & 282 & 72.31 \\
\hline Male & 108 & 27.69 \\
\hline \multicolumn{3}{|l|}{ Skin Color/Race } \\
\hline Black & 150 & 38.46 \\
\hline Brown & 209 & 53.59 \\
\hline White & 31 & 7.95 \\
\hline \multicolumn{3}{|l|}{ Level of Education } \\
\hline Illiterate/Incomplete Primary Education I & 226 & 58 \\
\hline Complete Primary Education I/Incomplete Primary Education II & 64 & 16.43 \\
\hline Complete Primary Education II/Incomplete High School & 50 & 12.83 \\
\hline Complete High School/Incomplete Higher Education & 45 & 11.54 \\
\hline Complete Higher Education & 5 & 1.20 \\
\hline \multicolumn{3}{|l|}{ Economic classification } \\
\hline B2 & 5 & 1.28 \\
\hline C1 & 18 & 4.62 \\
\hline $\mathrm{C} 2$ & 69 & 17.69 \\
\hline$D-E$ & 289 & 76.41 \\
\hline
\end{tabular}




\begin{tabular}{|c|c|c|}
\hline Variables & $\mathbf{N}$ & $\%$ \\
\hline \multicolumn{3}{|l|}{ Smoking } \\
\hline Yes & 145 & 37.18 \\
\hline No & 245 & 62.82 \\
\hline \multicolumn{3}{|l|}{ Alcohol consumption } \\
\hline Yes & 237 & 60.77 \\
\hline No & 153 & 39.23 \\
\hline \multicolumn{3}{|l|}{ Dyslipidemia } \\
\hline Yes & 71 & 18 \\
\hline No & 318 & 82 \\
\hline \multicolumn{3}{|l|}{ Diabetes Mellitus } \\
\hline Yes & 36 & 9.23 \\
\hline No & 354 & 90.77 \\
\hline \multicolumn{3}{|l|}{ Physical activity } \\
\hline Light & 172 & 44.10 \\
\hline Moderate & 77 & 19.74 \\
\hline Vigorous & 141 & 36.16 \\
\hline \multicolumn{3}{|l|}{ Fatty food consumption } \\
\hline$<1$ time/week & 130 & 33.33 \\
\hline 1 or 2 times/week & 113 & 28.98 \\
\hline 3 or 4 times/week & 147 & 37.69 \\
\hline \multicolumn{3}{|l|}{ Candy consumption } \\
\hline$<1$ time/week & 185 & 47.44 \\
\hline 1 or 2 times/week & 108 & 27.69 \\
\hline 3 or 4 times/week & 97 & 24.87 \\
\hline \multicolumn{3}{|c|}{ Daily intake of high-sodium foods } \\
\hline Yes & 69 & 17.69 \\
\hline No & 321 & 82.31 \\
\hline \multicolumn{3}{|l|}{ Adds salt to served food } \\
\hline Yes & 49 & 12.56 \\
\hline No & 341 & 87.44 \\
\hline \multicolumn{3}{|l|}{ Body mass index categories } \\
\hline Underweight & 11 & 2.82 \\
\hline Normal weight & 145 & 37.17 \\
\hline Overweight & 139 & 35.64 \\
\hline Classes I, II and III obesity & 95 & 24.37 \\
\hline
\end{tabular}

In the univariate logistic regression analysis, the risk factors associated with arterial hypertension were: smoking $(p=0.02)$ and BMI $(p=0.04)$. In the multivariate analysis, the the odds ratio with statistical significance for arterial hypertension were found for the predictors age and BMI. For systolic arterial hypertension alone, the only significant statistic preditor was age; as for diastolic arterial hypertension, the predictors were age, BMI and, primarily, economic class (Table 3).

The logistic regression model enabled us to identify the probability of developing arterial hypertension through increased
BMI. Among the sexes, the number of women was higher. According with the age and sex, it was noticeable that, as the quilombola population grows older, the number of hypertensives tends to increase, especially among women (Figure 1).

The Hosmer-Lemeshow test showed good adjustment/ calibration of the final model $(p=0.14)$. To assess the discrimination capacity of the model, the C-statistics was performed through calculation of the area under the ROC curve, presenting a value equal to 0.77 , which was considered a satisfactory value. 


\section{Original Article}

Table 3 - Predictors of systemic arterial hypertension in quilombola communities in the State of Sergipe, Brazil, 2016-2017

\begin{tabular}{|c|c|c|c|c|c|c|c|c|c|}
\hline \multirow{2}{*}{ Variables } & \multicolumn{3}{|c|}{$\mathrm{AH}$} & \multicolumn{3}{|c|}{ SAH } & \multicolumn{3}{|c|}{ DAH } \\
\hline & OR & $95 \% \mathrm{Cl}$ & $p$ & OR & $95 \% \mathrm{Cl}$ & $p$ & OR & $95 \% \mathrm{Cl}$ & $p$ \\
\hline Age & 1.05 & $1.03-1.06$ & $<0.001$ & 1.06 & $1.04-1.07$ & $<0.001$ & 1.02 & $1.01-1.04$ & $<0.001$ \\
\hline \multicolumn{10}{|l|}{ Sex } \\
\hline \multicolumn{10}{|c|}{ Female (ref. } \\
\hline Male & 0.71 & $0.38-1.33$ & 0.29 & 0.67 & $0.36-1.24$ & 0.24 & 0.98 & $0.48-2.01$ & 0.97 \\
\hline \multicolumn{10}{|l|}{ ABEP } \\
\hline \multicolumn{10}{|c|}{ B2-C2 (ref.) } \\
\hline$D-E$ & 1.75 & $0.93-3.28$ & 0.07 & 1.38 & $0.74-2.56$ & 0.29 & 2.47 & $1.22-5.03$ & 0.01 \\
\hline BMI & 1.05 & $1-1.11$ & 0.04 & 1 & $0.95-1.05$ & 0.84 & 1.10 & $1.03-1.17$ & 0.02 \\
\hline
\end{tabular}

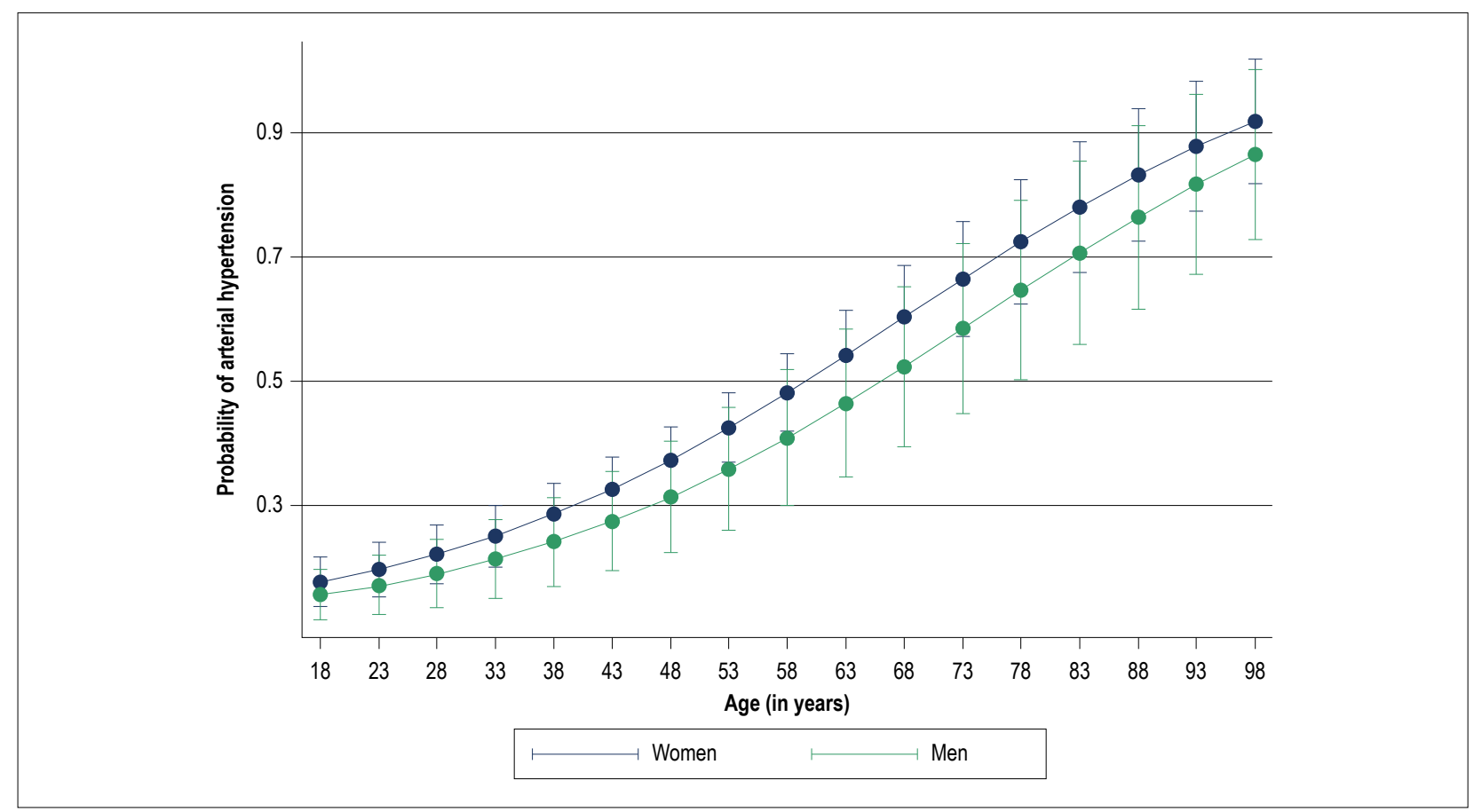

Figure 1 - Probability of arterial hypertension in Quilombola communities according to age and sex.

\section{Discussion}

The prevalence of SAH in the quilombola communities in the State of Sergipe (26\%) was high, when compared with the estimates of the population in general $(20.4 \%)$ in the same State, ${ }^{20}$ in similar age ranges.

In accordance with other studies in the general population developed in Brazil $^{21}$ and in other multiracial countries, ${ }^{22,23}$ the prevalence of SAH was associated with increased age. The black ethnicity showed a higher predisposition to arterial stiffness than the other ethnicities. ${ }^{24,25}$

aAlthough the prevalence of arterial hypertension was higher when compared to the general population, our results found a lower prevalence than other studies. ${ }^{6,7}$ This difference may be due to methodological issues (such as the number of measurements and the conditions under which they were performed), regional variations (for example, alcohol consumption and sodium ingestion) or even ethnic issues which remain unclear, beyond the scope of this study.

In this study, no significant sex-related differences were observed in the occurrence of SAH or its subclassifications (systolic and diastolic) among the quilombolas. This data stands in contrast to what is found in the literature in the context of the general population ${ }^{26}$ and the quilombola population. ${ }^{27}$ 
Concerning the modifiable variables, increased BMI was one of the major predictors associated with arterial hypertension. Cross sectional studies have shown such association and the damage to the health of the quilombola population, ${ }^{3}$ whose inadequate lifestyle choices may be a result of low income and education..$^{28}$

The prevalence of physical inactivity is this study was high. Probably, the idleness in rural areas promotes physical inactivity for most part of the months, when it is not harvest or planting time. This data corroborates with researches developed in rural ${ }^{29}$ and quilombola ${ }^{30}$ populations. This fact may have contributed for obesity and physical inactivity to foster the onset of arterial hypertension in the quilombola communities studied here.

It should be stressed that, when salt consumption was measured, low salt intake in this population may not have been accurately asessed, since sodium intake through processed or ultra-processed foods consumed everyday was not taken into consideration. ${ }^{31}$

The observed association between smoking and hypertension was significant in this study, which corroborates the results of other population-based studies. ${ }^{27,32}$ Another important data was alcohol consumption, which showed a high prevalence. However, this factor was not associated with arterial hypertension, corroborating the results of other studies developed in the quilombola communities..$^{21,30}$

Among the limitations of this research, we can mention the fact that the participants were volunteers, that is, the communities were randomly selected and the sample size was determined in advance, but the the enrolment was voluntary. In addition, part of the male population was not accessible, because they were working in the fields or fishing when the visits took place. The presence of diabetes and dyslipidemia has not been investigated, since glucose and lipid measurements, respectively, were not performed and the mere response of the individuals enrolled was avoided, because it could lead to biased information.

Future research should adequately assess these risk factors among the quilombolas to obtain better comprehension, since, as far as we know, this is the first study to approach this issue in the quilombola communities of the State of Sergipe.

\section{Conclusion}

The prevalence of arterial hypertension among the quilombolas was higher than in the general population. Age and increased BMI were the major predictors. This finding sugests the need for greater health care for the quilombolas, and serves as a baseline for the Brazilian government's development of health strategies in line with the the needs of ethnoracial communities.

\section{Author contributions}

Conception and design of the research: Santos DMS, Almeida-Santos MA; Acquisition of data: Santos DMS, Prado BS, Oliveira CCC; Analysis and interpretation of the data and Statistical analysis: Almeida-Santos MA; Writing of the manuscript and Critical revision of the manuscript for intellectual content: Santos DMS, Prado BS, Oliveira CCC, Almeida-Santos MA.

\section{Potential Conflict of Interest}

No potential conflict of interest relevant to this article was reported.

\section{Sources of Funding \\ This study was funded by CAPES e FAPITEC.}

\section{Study Association}

This article is part of the thesis of master submitted by Deyse Mirelle Souza Santos, from Universidade Tiradentes.

\section{Ethics approval and consent to participate}

This study was approved by the Ethics Committee of the Universidade Tiradentes under the protocol number 1.685.357. All the procedures in this study were in accordance with the 1975 Helsinki Declaration, updated in 2013. Informed consent was obtained from all participants included in the study.

\section{References}

1. Fundação Cultural Palmares. [Internet]. Certidões expedidas às comunidades remanescentes de quilombos. 2017. [Citado 10 Jan 2019]. Disponível em: https://www.palmares.gov.br/wp-content/uploads/2015/07/ cCOMUNIDADES-CERTIFICADAS -23-11-2018-site.pdf

2. Brasil. Casa Civil, Presidência da República. [Internet]. Decreto $n^{\circ} 4887$, de 20 de novembro de 2003. Regulamenta o procedimento para identificação, reconhecimento, delimitação, demarcação e titulação das terras ocupadas por remanescentes das comunidades dos quilombos de que trata o art. 68 do Ato das Disposições Constitucionais Transitórias. [Citado em 2018Mar 11]. Disponível em: http://www.planalto.gov.br/ccivil_03/decreto/2003/d4887.htm.

3. Bezerra VM, Andrade ACS, Cesár CC, Caiaffa WT. Unawareness of hypertension and its determinants among 'quilombolas' (inhabitants of 'quilombos' - hinterland settlements founded by people of African origin) living in Southwest Bahia, Brazil . Ciênc Saúde Colet. 2015;20(3):797-807.
4. Kimura L, Angeli CB, Auricchio MT, Fernandes GR, Pereira AC, Vicente JP, et al. Multilocus family-based association analysis of seven candidate polymorphisms with essential hypertension in an African-derived semiisolated Brazilian population. Int J Hypertens. 2012;30(1):85-92.

5. Kimura L, Ribeiro-Rodrigues EM, De Mello AMT, Vicente JP, Batista Santos SE, Mingroni-Netto RC. Genomic ancestry of rural African-derived populations from Southeastern Brazil. Am J Hum Biol. 2013;25(1):35-41.

6. Souza CL, Barroso SM, Guimarães MDC. Missed opportunity for timely diagnosis of diabetes mellitus in Afrodescendant communities in the southwest of the state of Bahia, Brazil.. Ciênc Saúde Colet. 2014;19(6):1653-62.

7. Bezerra VM, Andrade ACS, César CC, Caiaffa WT. Quilombo communities in Vitória da Conquista, Bahia State, Brazil: hypertension and associated factors. Cad Saúde Pública. 2013;29(9):1889-902. 


\section{Original Article}

8. Instituto Brasileiro de Geografia Estatística (IBGE). [Internet]. Percepção do estado de saúde, estilo de vida e doenças crônicas. Pesquisa Nacional de Saúde. 2013. [Citado 30 Maio 2018]. Disponível em: ftp://ftp.ibge.gov.br/ PNS/2013/pns2013.pdf.

9. Malachias MVB, Souza WKSB, Plavnik FL, Rodrigues CIS, Brandão AA, Neves MFT, et al.. 7aㅡ diretriz Brasileiras de Hipertensão Arterial. Arq Bras Cardiol. 2016;107(3 Supl 3):1-103.

10. Pereira M, Lunet N, Azevedo A, Barros H. Differences in prevalence, awareness, treatment and control of hypertension between developing and developed countries. J Hypertens. 2009;27(5):963-75.

11. Faul F, Erdfelder E, Lang AG, Buchner A. G* Power 3: a flexible statistical power analysis program for the social, behavioral, and biomedical sciences. Behav Res Methods. 2007;39(2):175-91.

12. Brasil. Ministério da Saúde. Guia alimentar para a população brasileira. Departamento de Atenção Básica. 2a. ed. Brasília; 2014.

13. Brasil. Ministério da Saúde. Avaliação de efetividade de programas de educação física no Brasil. Departamento de Análise de Situação em Saúde. Brasília; 2013.

14. Instituto Brasileiro de Geografia Estatística (IBGE). Pesquisa Nacional de Amostra por Domicílio: síntese de indicadores 2015. Rio de Janeiro; 2016.

15. Pilli L, Ambrósio B, Suzzara B, Pontes L, AlvesM, Reis M, etal. Associação Brasileira de Empresas de Pesquisa. Critério de classificação econômica Brasil.; 2014.

16. Henrique IFS, Micheli D, Lacerda RB, Lacerda LA, Formigoni MLOS. Validação da Versão Brasileira do Teste de Triagem do Envolvimento com Álcool, Cigarro e Outras Substâncias (ASSIST). Rev Assoc Med Bras. 2004;50(2):199-206

17. Caminal HJ, Casanova MC. La evaluación de la atención primaria y las hospitalizaciones por ambulatory care sensitive conditions. Marco conceptual. Aten Primaria. 2003;31(1):61-5.

18. Whelton PK, Carey RM, Aronow WS, Casey DE Jr, Collins KJ, Dennison Himmelfarb C, et al. 2017 ACC/AHA/AAPA/ABC/ACPM/AGS/APhA/ASH/ ASPC/NMA/PCNA Guideline for the prevention, detection, evaluation, and management of high blood pressure in adults: executive summary: a report of the American College of Cardiology/American Heart Association Task Force on Clinical Practice Guidelines. Hypertension. 2018;71(6):1269-324.

19. Lohman TG, Roche AF, Martorell R. Anthropometric standardization reference manual. Champaign: Human Kinetics Books,; 1991.

20. Instituto Brasileiro de Geografia Estatística (IBGE). [Internet]. Censo demográfico: características da população e dos domić́lios. 2013. [Citado 30 Maio 2018]. Disponível em: https://www.ibge.gov.br/estatisticas-novoportal/ multidominiocondicoes-de-vida-desigualdade-e-pobreza/9127-pesquisanacional-por-amostra-de-domicilios.html?edicao $=18329 \& \mathrm{t}=$ downloads.

21. Silva TSS, Bomfim CA, Leite TCR, Moura CS, Belo NO, Tomazi L. Hypertension and associated factors in a community quilombola of Bahia, Brazil. Cad Saúde Colet. 2016;24(3):376-83.

22. Pilleron S, Aboyans V, Mbelesso P, Ndamba-Bandzouzi B, Desormais I, Lacroix P, et al. Prevalence, awareness, treatment, and control of hypertension in older people in Central Africa: the EPIDEMCA study. J Amer Soc Hypertens. 2017;11(7):449-60.

23. Kheirallah KA, Liswi M, Alazab R, Bataineh Z, Alzyoud S, Alsulaiman J, et al. Hypertension prevalence, awareness and control levels among Ghawarna: an African-descendant ethnic minority in the Jordan valley. Ethn Dis. 2015;25(3):321-8.

24. Hae GS, Eung JK, Hong SS, Seong HK, Chang GP, Seong WH, et al. Relative contributions of diferente cardiovascular risk factors to significant arterial stiffness. Int J Cardiol. 2010;139(3):263-8.

25. Santos PC, Alvim RO, Ferreira NE, De Sá CR, Krieger JE, Mill JG, et al. Ethnicity and arterial stiffness in Brazil. Am J Hypertens. 2011;24(3):278-84.

26. Radovanovic CAT, Santos LA, Carvalho MDB, Marcon SS. Arterial hypertension and other risk factors associated with cardiovascular diseases among adults. Rev Latin-Am Enfermagem. 2014;22(4):547-53.

27. Melo JD, Trevisol DJ, Fernandes NB, Pereira MR. Systemic arterial hypertension and associated factors in the family health strategy in Imbituba/ SC. Rev AMRIGS. 2016;60(2):108-14.

28. Soares DA, Barreto SM. Overweight and abdominal obesity in adults in a quilombo community in Bahia State, Brazil. Cad Saúde Pública. 2014;30(2):341-54.

29. Bicalho PG, Hallal PC, Gazzinelli A, Knuth AG, Velásquez-Meléndez G. Adult physical activity levels and associated factors in rural communities of Minas Gerais State, Brazil. Rev Saúde Pública. 2010;44(5):884-93.

30. Ferreira HS, Silva WO, Santos EA, Bezerra MKA, Silva BCV, Horta BL. Body composition and hypertension: a comparative study involving women from maroon communities and from the general population of Alagoas State, Brazil. Rev Nutr. 2013;26(5):539-49.

31. Ford ES, Caspersen CJ. Sedentary behaviour and cardiovascular disease: a review of prospective studies. Int J Epidemiol. 2012;41(5):1338-53.

32. Rosário TM, Scala LCN, França GVA, Pereira MR, Jardim PCB. Factors associated to systemic arterial hypertension in Nobres-MT. Rev Bras Epidemiol. 2009;12(2):248-57. 
